\title{
Evaluation of Structure and Process of Governance in Souharda Cooperative: A Conceptual Analysis with Reference to Karnataka, India
}

\author{
Venkatesha, H.P. \\ Research Scholar, Post Graduate Centre, Hemagangothri, University of Mysore, Hassan-573201, Karnataka, India
}

Corresponding author: hpv1990@gmail.com

Received: 04-04-2019

Revised: 09-07-2019

Accepted: 22-08-2019

\begin{abstract}
In essence, the conceptual framework developed in this study includes the Souharda Act paving the way for freedom in operations; governance structure based on transparency, accountability and rule of law; governance process founded on democracy; and organizational performance to be measured through financial performance and non-financial performance. In essence, the Act (Level 1) paves the way for governance structure and governance process representing as 'hardware' and 'software' (Level 2) should lead to 'Organizational Performance' (Level 3) in cooperative governance. Such organizational performance is identified to be reflected in 'Financial Performance' and 'Non-Financial Performance.' Though cooperative societies are 'not-for-profit' institutions or 'service oriented' institutions, the cooperative structure and process enveloped with 'freedom' should strive to achieve 'Financial Performance' that should result in sustainability of the cooperative institution in the long run. All these three levels of cooperative governance are inter-linked and any gap in any of these levels indicates low or no governance.
\end{abstract}

Keywords: Cooperative Governance, Governance Structure, Governance process

The concept of cooperation was enunciated as a middlepath and was never a revolutionary concept, because the concept of cooperation existed long before the dawn of civilization itself. This assertion is true because groups of individuals around the world and right through time have worked together in pursuit of universal goals. Such attainment of common goals through cooperatives may be traced to pre-historic predecessors, who acknowledged the advantages of hunting, gathering and living in groups rather than on their own ${ }^{1}$. In fact, the natural reaction of people is to work together for their mutual benefit ${ }^{2}$. The inception of modern cooperatives started in England in 1884 by Rochdale Equitable Pioneers Society ${ }^{2}$. In fact, the essential roots of their structures, processes and the underlying rationale for those structures are attributed to the Rochdale principles even to this day. In recent times, the governance structures and processes in relation to cooperatives have moved to a higher level of "director accountability from shareholder liability and director immunity". By their very principles, cooperatives are governed by their members on the basis of the true spirits of democracy, especially in industrialized countries, though such democratic governance in developing countries is yet to take off on desired lines. Importantly there is a laxity of research on cooperative governance structure and process in India hence it is the right time have a look at problems and prospects of cooperative governance 
in Souharda cooperatives with a focus on structure and process since their beginning in 1997 so that this institution should be sustainable in the long run.

\section{Concepts of Cooperation}

Cooperation is founded on four important concepts that include (i) Cooperative, (ii) Corporate Governance and (iii) Cooperative Governance. Each of these concepts is briefly explanted below:

(i) Cooperative: "A cooperative is an autonomous association of persons united voluntarily to meet their common economic, social, and cultural needs and aspirations through a jointly owned and democratically controlled enterprise ${ }^{1}$." Another widely accepted definition of cooperative is provided by the United States Department of Agriculture (USDA) in 1987: "A cooperativeisauser-owned, user-controlled business that distributes benefits on the basis of use." This definition recognizes three primary cooperative principles: user ownership, user control, and proportional distribution of benefits. All 3ideas imply that members of cooperative govern the business directly by vote on vital and semi permanent business choices and indirectly through their representatives on the board of directors subject to the regulations by the government, and members share the benefits, costs, and risks of doing business in equal proportion to their patronage ${ }^{1}$.

(ii) Corporate Governance: Corporate governance is outlined as "the relationship between shareholders, creditors, and corporations; between financial markets, institutions and corporations, and between employees and corporations. Corporate governance would additionally cover the difficulty of company social responsibility, including aspects such as the dealings of the firm with respect to culture and the environment ${ }^{3}$." The buzzword in conducting the affairs of a firm or an economy revolves around governance vis-à-vis management. Governance refers to supervision and higher cognitive process associated with direction, monetary designing and structure policies that define the organization's purpose, values and structure. But management focuses on routine decisions and administrative work related to the daily operations of the organizations, mostly devoid of ethics and stewardship. Thus governance concept is overarched by ethical and stewardship considerations in carrying out the managerial duties of an enterprise.

(iii) Cooperative Governance: The Co-operative Governance handbook describes co-operative governance as "The set of relationships between the cooperative's members, the board as representatives of members and the executive that has care and control of the co-operatives for members and the process of governing the business in the best interests of its owners." In other words, cooperative governance can be defined as a system by which a cooperative is directed, controlled and held accountable for the manner in which power is exercised in the decision-making and business operation process of the cooperatives. In many ways, cooperatives are like other businesses ${ }^{4}$ and basically corporate governance is the same in cooperatives as in publicly quoted companies ${ }^{5}$. Co-operative governance differs from other forms of enterprises in the sense that a co-operative exists for fulfilling social objects and protection of the social interest of the society and, therefore, good governance must provide direction for its board and members to work in the interests of the cooperative and its members. The key differences in cooperative governance as compared to corporate governance are that each member of a cooperative generally has one vote, its directors be selected from among the members and cooperatives are designed to reduce the costs of goods and services ${ }^{6}$.

\section{Statement of the Problem}

Obviously, the issue of governance hinges on the degree of operational autonomy enjoyed by co-operatives. The structure and process of governance in co-operative enterprises in India cannot be compared with that of the cooperatives in industrialized countries mainly due to the state intervention model of legislative framework in most Indian states. However, Karnataka follows a duallegislation model (The Karnataka State Cooperative Act, 1959 applicable for conventional co-operatives and the Karnataka State Souharda Cooperative Act, 1997 under which autonomous cooperatives are established). The major difference between these two legislations is that Souharda cooperatives are bestowed with greater 
autonomy than the traditional cooperatives. With such autonomy being given to the Souharda cooperatives, it is pertinent to analyze as to whether they are able to create good governance structure and put in place a governance process that helps realizing the goals of good governance. Therefore, the governance structure and process is a critical problem to be investigated in the context of Souharda cooperatives.

\section{Conceptual Framework}

The beginning of any empirical research starts with developing the conceptual framework. Basically, a conceptual framework in research is used to understand the place of and direction of a research. A conceptual framework is used to make conceptual directions and organize research ideas with inter-linkages among the concepts and constructs so that reality behind a phenomenon is captured. In other words, a conceptual framework represents the researcher's synthesis of literature on how to explain a phenomenon by identifying the actions required in the course of the study. Sometimes, it is compared to a recipe or a blueprint that provides an outline of how a researcher plans to conduct the research and positioning the identified conceptual framework within the larger field of research documented in review of literature. In other words, developing a conceptual framework is followed by review of literature relating to theory and empirical findings of others. Thus a conceptual framework not only explains the relationships between factors in a given phenomenon, but also embodies the specific direction by which the research will have to be undertaken. In this sense, the conceptual framework is also known as research paradigm. A few observations on the nature of conceptual framework may be worth noting to understand it better.

From the perspective of statistical analysis, the conceptual framework makes an attempt to describe the relationships between the main concepts, factors or dimensions of the study. Such logical structural presentation provides a picture, a graphical presentation as a visual display of how ideas in a study related to one another ${ }^{7}$. It is also referred to as the series of actions in a sequence the researcher intends to carry out a research ${ }^{8}$.
The conceptual framework helps a research to easily specify and define the concepts within the problem of the study ${ }^{9}$. Such logical structural presentation provides a picture, a graphical presentation as a visual display of how ideas in a study related to one another ${ }^{7}$ or how the key variables or constructs are studied with the presumed relationships between them ${ }^{10}$. Lastly, a conceptual work is considered to be an embodiment of the whole research process.

Cooperative sector in Karnataka is governed by duallegislation model consisting of the Karnataka State Cooperative (KSC) Act, 1959 and the Karnataka State Souharda Cooperative (KSSC) Act, 1997. At present, a cooperative organization may be established under any of the above two Acts. When a cooperative institution is established under the KSC Act, 1959, such societies are under the direct control of the Government and they have less freedom in their operations but they may seek the government funds for their development and operations. When a cooperative institution is established under the KSSC Act, 1997, such societies are known as Souharda Cooperatives and they have almost complete freedom in adopting development strategies and operations without seeking government funds. Thus the societies registered under the 1959 Act may be termed as traditional societies and those registered under the 1997 Act are known as Souharda Cooperatives. The present study covers cooperative governance in Souharda Cooperatives of Karnataka State. The essential difference between traditional cooperatives and Souharda cooperatives lies in the degree of freedom vested with these types of societies. The traditional cooperatives do not have much freedom. Though Souharda cooperatives were vested with complete freedom in the original 1997 Act, the Government has been engaged in curtailing this freedom gradually with almost complete freedom or partial control due to abuse of this freedom by these societies.

However, the hallmark of these Souharda cooperatives has been 'freedom' in development and management. It is in this background of almost complete freedom characterized by partial government control of these Souharda cooperatives, the theoretical model of cooperative governance was developed as depicted in 
Fig. 1 for the present study in three levels: Level 1, Level 2 and Level 3 and these levels are highly interlinked. The conceptual framework for the purpose of the present study has been outlined under (i) Levels of Governance.; and (ii) Elements in Governance.

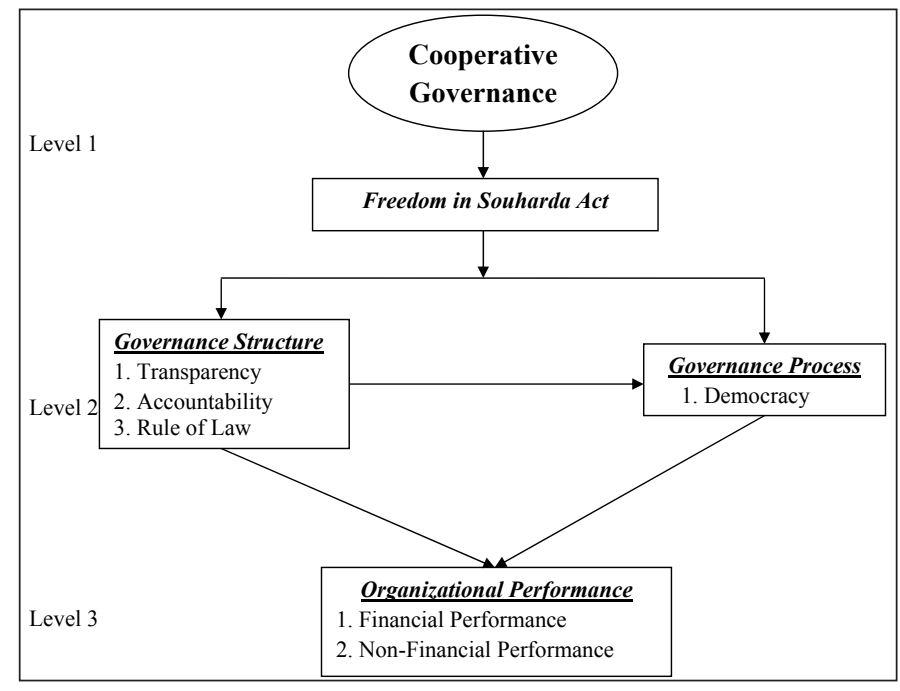

Fig. 1

Source: Own

\section{(i) Levels of Governance}

The conceptual framework developed for the presented has been briefly explained under three levels.

Level 1 relates to 'Freedom in Souharda Act' and it is the foundation on which cooperative governance is built up.

Level 2 envisages 'Freedom in Souharda Act' to be developed on a sound 'Governance Structure' based on the principles of 'Democracy' that guide 'Governance Process.' Though governance structure is directly visible with the formation of a board, sub-committees established by the board with employees being staffed, these should work with high coordination and unison to realize effective cooperative governance.

The governance structure represented by human resources is expected to achieve the vision and mission of a Souharda cooperative based on the principles of 'Transparency,' 'Accountability,' and 'Rule of Law.' However, the rider on these three principles has been envisagedintheconceptualmodelintermsof' Democracy,' which points towards treating all stakeholders with equity. As nouns, the difference between structure and process is that structure is cohesive whole built up of distinct parts with an emphasis on conducting business with ethical content, while process is a series of events on the principles of democracy to produce a result. In nutshell, if governance 'structure' is the 'hardware' of a cooperative institution, governance 'process' is the 'software' of such an institution. Extending further, if there is weak or wrong 'software,' then the hardware is ineffective and becomes dysfunctional.

Level 3 envisages the study of 'Organizational Performance,' which is founded on Governance Structure" and Democracy," which in turn are the results of Souharda Act that signifies almost complete freedom in cooperative governance.

\section{(ii) Elements in Governance}

The conceptual framework is an embodiment of different elements, which may also be called factors or dimensions. These elements include (a) Legislation; (b) Democracy; (c) Transparency; (d) Accountability; (e) Rule of Law; and (f) Organizational Performance. These seven elements of cooperative governance included in the conceptual framework have been briefly explained below.

(a) Legislation: The heart of cooperative governance in Souharda cooperatives has been the freedom in operations and this freedom is given to Souharda cooperatives by passing an Act to that effect through legislative process. Legislation is a law which has been promulgated or enacted by a legislature or other governing body of the process of making it. It is simply the process of making or enacting laws. Philosophy of legislation in terms of "utility" to the society at large and defines utility as principle in these words: "By the principle of utility is meant that principle which approves or disapproves of every action whatsoever according to the tendency it appears to have to augment or diminish the happiness of the party whose interest is in question: or, what is the same thing in other words to promote or to oppose that happiness... By utility is meant that property in any object, whereby it tends 
produce benefit, advantage, pleasure, good, happiness, to prevent the happening of mischief, pain, evil, or unhappiness to the party whose interest is considered; if that party be the community in general, then the happiness of the community; if a particular individual, then the happiness of that individual ${ }^{11}$." Thus any legislation should serve the individual or society at large. Generally, legislation is made by legislature, which may be at the central or state level in any country.

An extension of legislation is the "Act," which is named when the legislature passes a Bill to that effect. Any act sets out the broad legal or policy principles. It also specifies 'dos' and 'dont's.' An act is a constitutional plan that is created by the government through the legislative process by passing a bill. It also includes rules and regulations passed by the legislature. Any act is passed by legislative bodies, which is a representative governmental body in which the will of the people is transferred into the will of a state in the form of law, which has superior (after Constitution) legal force. The present study proceeds with the main features of Souharda Act, 1997 of Karnataka.

Generally speaking, freedom refers to the power or right to act, speak or think as one wants. However, freedom stands for something greater than just the right to act. It also stands for securing to everyone an equal opportunity for life, liberty, and the pursuit of happiness for all. The importance of freedom lies in the fact that people have the opportunity to speak, act and pursue happiness to oneself and others without unnecessary external restrictions. Its importance may also be summed up in the enhanced expressions of creativity and original thought one's quality of life and also of others. "Freedom, like love and beauty, is one of those values better experienced than defined." Further, explain the 3aspect of autonomy with three types of autonomy that consist of personal autonomy, sovereign autonomy, and civic autonomy with personal autonomy representing both the absence of cruelty and the ability to do as one pleases within the limits of other person's wishes to do as they please, with sovereign autonomy representing the authority to act as one pleases regardless of the desires of other people, and civic autonomy representing the aptitude of public to participate in public life, especially governance ${ }^{12}$. Of these three types of autonomy, the most important autonomy is the civic autonomy that directs the cooperative governance through the enactment of Karnataka Souharda Cooperatives Act, 1997. Thus the whole process of governance in Souharda cooperatives stems from this Act, which derives its strength from the rules, regulations and guidelines issued by the Government from time to time along with the bye-laws adopted by these societies. Thus the legislation process paving the way for the Act is the overarching dimension in the conceptual framework for the study of cooperative governance in Souharda cooperatives in Karnataka.

(b) Democracy: Democracy is the most important concept emanating from the Souharda Cooperative Act in the sense that the whole functioning of Souharda cooperatives should be based on democratic principles. Democracy could be a system of state by the full population or all the eligible members of a state, typically through elected representatives. Typically, democracy "is government by the folks within which the supreme power is unconditional within the folks and exercised directly by them or by their elected agents below a free voting system." In essence, democracy is the institutionalization of freedom. In his Gettysburg Address, Abraham Lincoln defines democracy as a "government of the people, by the people and for the people. It is in this true spirit of democracy, all individuals and institutions are expected to behave and work. Lastly, it is important to note that all institutions, whether established by the government or individuals as a group are expected to operate in a democratic way and so are the Souharda cooperative societies under the Karnataka Souharda Cooperative Societies Act, 1997.

(c) Transparency: The words 'transparency' and 'transparent' are creeping as bull's eye into the public's vocabulary and into political and policy academic writings ${ }^{13}$. Transparency refers to "trustworthiness of the actor in negotiation ${ }^{14}$." The most comprehensive definition of transparency has been provided: "Transparency comprises the legal, political, institutional structures that make information about the internal characteristics of a government and society available to actors both inside and outside the domestic political system ${ }^{15}$. Transparency is raised by any mechanism that 
ends up in the general public speech act of knowledge, whether a free press, open government, hearings or the existence of nongovernmental organizations with an incentive to release objective information about the government [or the institution]." It is also observed that transparency is intertwined with accountability, transparency encourages openness, and policy makers create transparency alongside accountability, efficiency, and effectiveness. Lastly, transparency refers to a condition in which business and economic actions and their recording are done in an open system without hiding any relevant information or without opaque so that folk's can faith that they are fair and honest.

(d) Accountability: Accountability is an ethical concept that denotes "answerability, blameworthiness, liability and the expectation of account-giving ${ }^{16}$." Accountability is the focus of governance discussions related to problems in the public sector, non-profit organizations, private corporate bodies and also individuals. As the central conception of leadership, "Accountability is that the acknowledgement and assumption of responsibility for actions, products,, decisions, and policies as well as administration, governance, and implementation among the scope of the role or employment position and encompassing the obligation to report, explain and be answerable for resulting consequences ${ }^{17}$." In governance literature, accountability has expanded beyond the basic definition of "being called to account for one's actions ${ }^{18-19}$." Hence accountability has broader implications in the sense that it is described as an account-giving relationship between any two parties or amongst parties. Thus accountability refers to the fact of being responsible for what an institution or individual does and being able to give a satisfactory reason for it. It refers to owning up for one's acts or behavior.

Accountability is thrust on an organization for several reasons. Accountability is a principle of governance structure and it is intertwined with culture of an organization. In management, accountability is not similar to responsibility and it is more important than responsibility. The main difference between the two is that responsibility can be shared while accountability cannot be shared and it is to be individually or jointly to be owned up. Accountability indicates taking decisions and doing work in good faith and this approach eliminates the time and effort on distracting activities and other unproductive behavior. Another important advantage of accountability is that it leads to success. Accountability is considered to be a source of success. It is also posited that "Successful people are always accountable."

(e) Rule of Law: The English lexicon defines rule of law as "the authority and influence of law in society, particularly once viewed as a constraint on individual and institutional behavior; [and hence] the principle whereby all members of a society (including those in government) square measure thought of equally subject to publically disclosed legal codes and processes." The General defines rule of law as "a principle of governance during which all persons, establishments and entities, public and personal, together with the State itself, square measure responsible to laws that square measure publically published, equally enforced and severally adjudicated, and that square measure per international human rights norms and standards ${ }^{20}$. It needs, as well, measures to make sure adherence to the principles of ascendency of law, equality before the law, answerability to the law, fairness within the application of the law, separation of powers, participation in decision-making, legal certainty, turning away of capriciousness and procedural and legal transparency." Rule of law refers to the principle that each one folks and establishments subject to and accountable to law that is fairly and equally applied and enforced. It conjointly imposes a restriction on the absolute exercise of power by subordinator it to well-defined and established law. There are five principles that describe the rule of law as given below: (i) the management and the related players are responsible are responsible beneath the warrant; (ii) the requirements of rule of law are open, promulgated, and resolute; (iii) the laws should be fairly, consistently, equally, reasonably implemented to protect the security of persons, contract, property and human rights; (iv) the process by which the laws should be enacted, administered, and enforced with features of promulgation, accessibility, fair, efficiency, and perpetuity; and (v) the appeals by relevant parties should be resolved by the deputies or implementers with 
autonomy, morality, without bias and self-governance. An important advantage of rule of law is that it helps to ultimately preserve the constitution of the land.

(f) Organizational Performance: Any legally established institution established under any Act legislated by the legislative bodies are expected to operate a democratic way characterized by transparency, accountability and rule of law resulting in institutional or organizational performance ultimately. Organizational performance refers to the actual productivity or results of an organization as measured against its intended outputs, also known as goals and objectives, by adopting various strategies that cover planning, operations, legal, finance and organizational development with effectiveness and efficiency. Efficiency refers to assessing and evaluating how the resources of an organization are economically utilized through the accomplishment of functions to achieve its objectives. The above components of organizational performance are generally applicable to profit-making institutions. The cooperative institutions are normally obligated to achieve non-financial performance with a tinge of financial performance, the latter being also important in the long run. Hence organizational performance in the context of cooperative governance may be defined as achieving the broader perspectives of society as well as achieving the narrow perspective of achieving sustaining financial performance.

\section{CONCLUSION}

This study is the first of its kind in India with a focus on the effectiveness of structure and process towards cooperative governance with a thrust on Souharda cooperatives in Karnataka. And most importantly the study contributes to identify the well-built factors that represent the governance structure and process evaluation. In essence, the Act (Level 1) paves the way for governance structure and governance process representing as 'hardware' and 'software' (Level 2) should lead to 'Organizational Performance' (Level 3 ) in cooperative governance. Such organizational performance is identified to be reflected in 'Financial Performance' and 'Non-Financial Performance.' Though cooperative societies are 'not-for-profit' institutions or 'service oriented' institutions, the cooperative structure and process enveloped with 'freedom' should strive to achieve 'Financial Performance' that should result in sustainability of the cooperative institution in the long run. All these three levels of cooperative governance are inter-linked and any gap in any of these levels indicates low or no governance. In the background of this conceptual model, the empirical study of cooperative governance in Souharda cooperative societies was carried out with a comprehensive framework that consisted of transparency in board's operations, accountability shareholders and also stakeholders with adherence to rule of law under the umbrella of democracy leading to sustainable management and development by maintaining high standards of business ethics and integrity.

To conclude on the conceptual framework of the present study on cooperative governance, the relevant issues for empirical analysis include evaluating the perceptions of select respondents towards the Souharda Act that provides ample freedom to run the Souharda cooperatives based on the principles of democracy, which is made operational by adopting the principles of transparency, accountability and rule of law to realize an effective and efficient organizational performance characterized by more of non-financial performance than of financial performance.

\section{REFERENCES}

1. Zeuli, K.A. and Cropp, R. 1980. Cooperatives: principles and practices in the $21^{\text {st }}$ century. University of Wisconsin Extension-Madison, publication A1457. http://www. communitywealth.org/ (accessed 03/09/07).

2. Ruiz-Mier, F. and van Ginneken, M. 2006. Consumer cooperatives: An alternative institutional model for delivery of urban water supply and sanitation services. Water Supply and Sanitation Board.

3. Claessens, S. 2003. Corporate Governance and Development Global Corporate Governance Forum Focus 1 Washington: World Bank.

4. Zeuli, K.A., Cropp, R. and Schaars, M.A. 2004. Cooperatives: Principles and practices in the $21^{\text {st }}$ century.

5. Pellervo, 2000. Corporate governance and management control in cooperatives. Confederation of Finnish Cooperatives November, 2000. 
6. Olsen, B.T. and Brunn, A. 2003. Governance and Cooperatives: The search for a Model. Mapping co-operative Studies in the new millennium, Victoria, Canada.

7. Osanloo, A. and Grant, C. 2016. Understanding, selecting, and integrating a theoretical framework in dissertation research: Creating the blueprint for your "house". Administrative issues journal: connecting education, practice, and research, 4(2): 7.

8. Dixon, J.A., Gibbon, D.P. and Gulliver, A. 2001. Farming systems and poverty: improving farmers' livelihoods in a changing world. Food \& Agriculture Org..

9. Luse, A., Mennecke, B.E. and Townsend, A.M. 2012. Selecting a research topic: A framework for doctoral students. International Journal of Doctoral Studies, 7: 143.

10. Miles, M.B., Huberman, A.M., Huberman, M.A. and Huberman, M. 1994. Qualitative data analysis: An expanded sourcebook. sage.

11. Bentham, J. 2000. An Introduction to the Principles of Morals and Legislation, impresoen 1781 y publicadoen 1789.

12. Patterson, O. 1991. Freedom in the making of western culture (Vol. 1). IB Tauris.
13. Ball, C. 2009. What is transparency?. Public Integrity, 11(4): 293-308.

14. Clark, D.H. and Reed, W. 2005. The strategic sources of foreign policy substitution. American Journal of Political Science, 49(3): 609-624.

15. Finel, B.I. and Lord, K.M. 1999. The surprising logic of transparency. International Studies Quarterly, 43(2): 315-339.

16. Dykstra, C.A. 1939. The quest for responsibility. American Political Science Review, 33(1): 1-25.

17. Williams, Reyes. 2006. Leadership accountability in a globalizing world, London: Palgrave Macmillan.

18. Sinclair, A. 1995. The chameleon of accountability: forms and discourses. Accounting, organizations and Society, 20(2-3): 219237.

19. Schedler, A., Diamond, L.J. and Plattner, M.F. (Eds.). 1999. The self-restraining state: power and accountability in new democracies. Lynne Rienner Publishers.

20. General, U.S. 2004. The rule of law and transitional justice in conflict and post-conflict societies. Report of the SecretaryGeneral, S/2004/616, August. 